\title{
VALUE ADDITION TO BIODIVERSITY PRODUCTS FOR BIOPROSPE.CTING AND BENEFIT SHARING
}

\author{
${ }^{1}$ DKNG Pushpakumara, ${ }^{1} \mathrm{HB}$ Kotagama, ${ }^{1} \mathrm{~B}$ Marambe, ${ }^{2} \mathrm{G}$ Gamage, ${ }^{2} \mathrm{KAID}$ Silva, \\ ${ }^{1}$ LHP Gunarathne and ${ }^{3} S$ Wijesundara \\ ${ }^{1}$ Faculty of Agriculture, University of Peradeniya, Peradeniya \\ ${ }^{2}$ Ministry of Environment and Natural Resources, Battaramulla \\ ${ }^{3}$ Royal Botanic Garden, Peradeniya
}

Sri Lanka has been identified as a biodiversity hotspot in the world. This is because of her rich diversity at genes, species and ecosy stem levels and unprecedented rate of loss of

Such biodiversity. Sharing of benefits and increase in the recognized value of resources have been considered as one of the most effective pathways to foster conservation and utilization of biodiversity. Bioprospecting is searching for new genes, species and /or products for utilization, which has been practiced for centuries in Sri Lanka and elsewhere. However, to reach the optimum benefit of bioprospecting and benefit sharing, it is essential to understand the value addition processes to biodiversity products. Value addition is considered as a step taken to increase the value of a raw product any time between the harvesting and sale of the final product. Value added products not only offer a higher return, but also open new markets, create brand recognition and add variety. Value addition to biodiversity products can be rewarding and benefits accrue from matching under-utilised resources with potential markets.

The objectives of this study were to explore different value addition pathways of biodiversity products and identify sharing of benefits in each value addition process using Exacum trinervium (binara), Salacia reticulate (kotalahimbutu), Munronia pinnata (binkohomba), Santalum album (suduhandun) and Coscinium fenestratum (venival gata). Information was collected from personal communication (indigenous knowledge), literature survey and brain storming discussions.

Potential value addition pathways wcre identified for all species. Sharing of benefits occurs throughout the value addition processes, although magnitude of sharing between different steps varies with species. In majority of species higher level of benefits is received by middleman where as in M. pinnata, collectors share high level of benefits. Results of the study also revealed that there are no benefits provided in return to the area of conservation, which is a key factor of determining sustainability of conservation. Implications of understanding of value addition processes of biodiversity prospecting, requirements of establishment of national legislation on biodiversity prospecting, value addition and benefit sharing, and development of procedures and institutional capacities to implement such legislation are also discussed in this paper. 